\title{
Hubungan Identitas Etnis dan Kesadaran Budaya dengan Kecenderungan Perilaku Sopan Santun pada Siswa Kelas X SMK Mataram Semarang
}

\author{
Dhika Indahsari Kurnia $^{1}$ dan Heru Mugiarso ${ }^{2}$ \\ 1,2 Program Studi Bimbingan dan Konseling, Universitas Negeri Semarang \\ e-mail: dhiikakurnia@gmail.com
}

\begin{abstract}
ABSTRAK. Penelitian ini bertujuan (1) Membuktikan tingkat hubungan identitas etnis (2) Membuktikan tingkat hubungan kesadaran budaya, dan (3) mengetahui gambaran hubungan antara identitas etnis dan kesadaran budaya dengan kecenderungan perilaku sopan santun pada siswa kelas X SMK Mataram Semarang. Penelitian ini termasuk ke dalam penelitian kuantitatif korelasional, dengan jumlah populasi sebanyak 218 siswa dengan jumlah sampel 135 siswa pada kelas X SMK Mataram Semarang, dipilih dengan menggunakan teknik pengumpulan data teknik purposive sampling. Pengumpulan data dilakukan dengan skala kecenderungan perilaku sopan santun, skala identitas etnis, dan skala kesadaran budaya yang telah di uji validitas dan reliabilitasnya. Dalam analisis data pada penelitian ini menggunakan (1) analisis deskriptif untuk mengetahui tingkat identitas etnis, kesadaran budaya dan kecenderungan perilaku sopan santun, (2) analisis regresi linier berganda untuk mengetahui dan membuktikan ada atau tidaknya hubungan antara identitas etnis dan kesadaran budaya dengan kecenderungan perilaku sopan santun pada siswa. Hasil analisis data menunjukkan bahwa identitas etnis dan kesadaran budaya memiliki pengaruh yang signifikan terhadap kecenderungan perilaku sopan santun dengan perolehan $\mathrm{R}=0,481 ; \mathrm{R} 2=0,232 ; \mathrm{F}=19,918$; dan nilai sig=0,000. Nilai taraf signifikansi sebesar $0,000(\mathrm{P}<0,05)$ menunjukkan bahwa identitas etnis dan kesadaran budaya berhubungan secara signifikan terhdap kecenderungan perilaku sopan santun.
\end{abstract}

Kata kunci: Identitas Etnis;Kesadaran Budaya;Perilaku Sopan Santun

\section{Pendahuluan}

Perilaku merupakan bagian dari budi pekerti yang dapat membentuk sikap terhadap manusia, tuhan, diri sendiri, keluarga, masyarakat, bangsa dan alam sekitar. Perilaku sopan santun adalah peraturan hidup yang timbul dari hasil pergaulan sekelompok manusia di dalam masyarakat yang dianggap sebagai tuntutan pergaulan sehari-hari. Perilaku sopan santun merupakan unsur penting dalam kehidupan bersosialisasi sehari-hari pada setiap orang, karena dengan menunjukkan sikap sopan santun seseorang dapat merasa dihargai dan disenangi keberadannya sebagai mahkluk sosial dimanapun ia berada. Dapat dikatakan bahwa sopan santun yaitu norma tidak tertulis yang mengatur bagaimana seharusnya seseorang dalam bersikap dan berperilaku. Sopan santun merupakan istilah bahasa jawa yang dapat diartikan sebagai perilaku seseorang yang menjunjung tinggi nilai-nilai unggah-ungguh.

Selain itu Santun adalah wujud konkrit dari budya, sedangkan budaya itu sendiri merupakan perilaku, pola-pola, nilai-nilai yang diturunkan turun temurun dalam suatu masyarakat. Salah satu 
wujud sopan santun yang sering ditemukan adalah santun atau menghormati orang yang lebih dewasa saat berkomunikasi, berperilaku dan berbahasa. Dalam budaya masyarakat jawa tata karma dalam bentuk bahasa terbagi menjadi beberapa tingkat yakni Krama Inggil, Basa, dan Ngako. Dari beberapa tingkatan tersebut masyarakat menggunkannya dalam kehidupan seharihari tidak lain dan tidak bukan termasuk remaja/siswa sendiri. Namun masih banyak remaja yang kurang memaknai perilaku sopan santun tersebut sehingga tidak sedikit dan tidak jarang kita temui anak yang kurang memilki nilai sopan santun terhadap orang yang lebih tua.

Perilaku sopan santun ditentukan oleh berbagai faktor lingkungan yang mengelilinginya, baik faktor internal maupun eksternal. Dikatakan demikian karena pendidikan sopan santun tidak dapat berdiri sendiri karena saling keterkaitan dengan hal lainnya. Kemungkinan keterkaitan perilaku sopan santun dalam keluarga akan kelihatan dalam perilaku di masyarakat, dan pendidikan di masyarakat akan berkaitan dengan pendidikan di sekolah. Hal ini sudah diakui oleh banyak orang, (Suharti, 2004 : 99). Salah satu yang mempengaruhi perkembangan perilaku sopan santun anak adalah proses perlakuan atau bimbingan orang tua terhadap anak dalam mengenalkan berbagai aspek kehidupan sosial, atau norma-norma kehidupan bermasyarakat serta mendorong dan memberikan contoh kepada anaknya bagaimana menerapkan norma-norma tersebut dalam kehidupan sehari-hari.

Salah satu tempat dalam mengembangkan perilaku adalah lingkungkan keluarga atau dan teman sebaya, lingkungan keluarga adalah sekolah pertama bagi anak atau siswa dalam belajar, sehingga keluarga adalah tempat pertama kali anak untuk saling berinteraksi dan sharing terkait masalah antar anggota keluarga. Adapun fungsi keluarga adalah saling memperhatikan anggota keluarga, terbuka, jujur, saling mendengarkan, menghargai berbagai pendapat, dan mencintai seluruh anggota keluarganya tersebut. Orang tua adalah orang terdekat dan merupakan pendidik pertama dan utama bagi seorang anak. Karena sebelum memasuki usia prasekolah dan hingga usai sekolah, seorang anak sudah menerima pendidikan soal nilai-nilai hidup dari orangtua. Peran orangtua bagi pendidikan anak adalah memberikan dasar pendidikan sikap, keterampilan dasar seperti pendidikan agama, budi pekerti, sopan santun, estetika, kasih sayang, rasa aman, dasardasar untuk mematuhi peraturan dan menanamkan kebiasaan-kebiasaan.

Perilaku sopan santun sangatlah ditingkatkan terutama jika tinggal di lingkungan masyarakat jawa. Perilaku sopan santun adalah peraturan hidup yang timbul dari pergaulan sekelompok manusia didalam suatu masyarakat itu dan dianggap sebagai tuntutan pergaulan sehari-hari masyarakat tersebut. Sopan santun disnini merupakan istilah bahasa jawa yang dapat diartikan sebagai perilaku sesorang yang menjunjung tinggi nilai-nilai, menghormati, menghargai dan berakhlak mulia maka dari itu jika mengatakan sopan santun pasti akan erat kaitanya dengan budaya jawa. Sopan santun juga bisa dianggap sebagai norma yang tidak tertulis yang mengatur bagimana seharusnya kita bersikap atau berperilaku. Perilaku sopan santun tersebut dapat dilakukan dimana saja dan kapan saja sesuai dengan kebutuhan lingkungan tempat dan waktu karena sopan santun bersifat relative dimana yang dianggap sebagai norma sopan santun berbeda setiap tempatnya seperti dalam lingkungan rumah, sekolah, kampus, pergaulan, dan lain sebagainya.

Menurut Phinney \& Ong (2007) identitas etnis adalah perasaan yang menunjukan eksplorasi dan komitmen terhadap latar belakang etnisnya. Dimana terdapat dua komponen yaitu komponen eksplorasi dan komponen komitmen. Sehingga karakteristik identitas etnis dapat 
dilihat melalui bagaimana individu mencari tahu informasi mengenai etnis, pengalaman individu dalam memahami latar belakang etnis, pengalaman individu dalam mempelajari kelompok etnis, perasaan yang kuat terhadap etnis, keterikatan individu terhadap kelompok etnis, dan makna anggota kelompok etnis bagi individu tersebut. Selain itu Darity (2005) mendefinisikan bahwa etnik adalah kelompok yang berbeda dari kelompok yang lain dalam suatu masyarakat yang dapat dilihat dari aspek budaya. Dengan kata lain etnik adalah kelompok yang memiliki cirri-ciri budaya yang membedakkanya dari kelompok lain. Ciri budaya yang membedakannya dapat dilihat dari beberapa aspek seperti kekhasan sejarah, nenek moyang, bahasa dan symbol-simbol yang lain, seperti : pakaian, agama dan tradisi. Sehingga definisi tersebut dapat dikatakan saling melengkapi satu sama lain, dimana eksistensi kelompok dan cirri khas kelompok tertentu dapat disadari sendiri oleh setiap kelompok etnis

\section{Metode}

Dalam penelitian ini jenis penelitiannya termasuk penelitian kuantitatif karena dalam penelitian ini bertujuan untuk mengetahui nilai hubungan antara dua variabel atau lebih dengan menggunakan hasil yang berupa data berbentuk angka. Arikunto (2006:12) mendefinisikan penelitian kuantitatif merupakan suatu penelitian yang menggunakan angka dalam mengumpulkan data dan memberikan penafsiran terhadap hasilnya. Sedangkan menurut Azwar (2011 : 5) penelitian kuantitatif menekankan pada analisis yang diolah dengan metode statistika pada data yang berupa angka, dan dilakukan pada penelitian inferensial untuk menguji hipotesis, serta menyadarkan kesimpulan pada suatu probabilitas kesalahan hipotesis nihil. Metode penelitian ini digunakan untuk meneliti populasi dan sampel dengan kriteria tertentu umumnya pada teknik pengambilannya dilakukan secara random. Yang kemudian pengumpulan datanya menggunakan instrument yang dianalisis dan datanya bersifat kuantitatif yang bertujuan untuk uji hipotesis yang telah dirancang sebelumnya. Tujuan pada penelitian ini adalah untuk membuktikan atau mengetahui adanya hubungan antara identitas etnis dan kesadaran budaya dengan kecenderungan perilaku sopan santun pada siswa di SMK Mataram.

Dalam penelitian ini desain penelitian yang digunakan adalah jenis penelitian ex post facto dimana dalam penelitian ini tidak memberikan perlakuan atau eksperimen terhadap objek yang akan diteliti. Sehingga penelitian ini memiliki tujuan untuk mengetahui adanya hubungan antar satu variabel dengan variabel lainnya. Adapun variabel-variabel yang akan diteliti dalam penelitian ini yaitu Variabel independen (variabel bebas) dalam penelitian ini adalah identitas etnis (X1) dan kesadaran budaya (X2). Sedangkan Variabel dependen (variabel terikat) dalam penelitain ini adalah kecenderungan perilaku sopan santun $(\mathrm{Y})$.

Subyek dalam penelitian ini adalah siswa kelas X SMK Mataram Semarang dengan jumlah poluasi keseluruhan kelas X sebanyak 218. Pada teknik pengambilan sampel menggunkan teknik purposive sampling dengan tidak memberikan peluang yang sama bagi setiap anggota populasi. Kriteria yang ditentukan dalam penelitian ini yaitu siswa yang memiliki kecenderungan perilaku sopan santun dengan skor rata-rata tinggi. Merujuk pada rumus tabel Issac Michael dengan tingkat kesalahan 5\% maka sampel yang digunakan dalam penelitian ini yaitu 135 siswa. Pada pengumpulan data dalam penelitian ini menggunakan skala psikologis dengan tiga skala yaitu skala identitas etnis, skala kesadaran budaya, dan skala kecenderungan perilaku sopan santun dengan tingkatan skala likert. Dari hasil Validitas dan Reliabilitas skala yang valid dan reliabilitas 
dalam penelitian ini yaitu skala identitas etnis 24 item, skala kesadaran budaya 20 item, dan skala kecenderungan perilaku sopan santun 31 item.

Dalam penelitian ini teknik analisis data yang digunakan yaitu deskriptif kuantitatif dan regresi ganda. Analisis regresi ganda digunakan oleh peneliti, apabila peneliti bermaksud untuk meramalkan bagaimana keadaan (naik turunnya) variabel dependen (kriterium), apabila dua atau lebih variabel independen sebagai faktor predictor dimanipulasi (dinaik turunkan nilainya) (Sugiyono, 2014 : 275). Dalam penelitian ini analisis regresi ganda digunakan untuk melihat ada atau tidaknya hubungan antara identitas etnis dan kesadaran budaya dengan kecenderungan perilaku sopan santun pada siswa kelas X SMK Mataram Semarang. Dalam menganalisi regresi ini dilakukan dengan menggunakan bantuan SPSS 16.0

\section{Temuan}

Berikut ini Berdasarkan hasil analisis deskriptif ini akan menggambarkan kondisi rata-rata tingkat kecenderungan perilaku sopan santun, identitas etnis dan kesadaran budaya yang ada pada diri siswa disesuaikan dengan indicator pada masing-masing variabel. Untuk mengetahui tingkatan tinggi rendahnya setiap variabel dapat dilihat sebagai berikut :

1. Tingkat Kecenderungan Perilaku Sopan Santun pada Siswa Kelas X SMK Mataram Semarang

Tingkat indikator kecenderungan perilaku sopan santun akan menunjukkan seberapa tinggi perilaku sopan santun pada siswa. Untuk mengetahui kriteria analisis deskriptif pada setiap variabel dapat dilihat pada tabel 4.1 dibawah ini :

Tabel 1. Kriteria Tingkat Analisis Deskriptif Variabel Perilaku Sopan Santun

\begin{tabular}{ccc}
\hline No & Kelas Interval & Kategori \\
\hline 1 & $124-155$ & Sangat Tinggi \\
2 & $103-123$ & Tinggi \\
3 & $83-102$ & Sedang \\
4 & $62-82$ & Rendah \\
5 & $31-61$ & Sangat Rendah \\
\hline
\end{tabular}

Data indikator perilaku sopan santun di bawah akan menunjukkan seberapa tinggi tingkat perilaku sopan santun pada siswa kelas X di SMK Mataram Semarang. Dianalisis pada setiap indikator secara keseluruhan berdasarkan rata-rata. Adapun tingkat data indicator perilaku sopan santun disajikan dalam tabel sebagai berikut: 
Tabel 2. Hasil Analisis Tingkat Kecenderungan Perilaku Sopan Santun

\begin{tabular}{|c|c|c|c|c|c|c|}
\hline Variabel & Indikator & $\mathbf{N}$ & Min & Max & Mean & $\begin{array}{c}\text { Std. } \\
\text { Deviation }\end{array}$ \\
\hline $\begin{array}{l}\text { Kecenderungan } \\
\text { Perilaku Sopan }\end{array}$ & $\begin{array}{l}\text { Menghormati Orang yang } \\
\text { lebih tua }\end{array}$ & 135 & 24 & 45 & 34,20 & 4,115 \\
\hline \multirow[t]{6}{*}{ Santun } & $\begin{array}{l}\text { Menerima sesuatu dengan } \\
\text { tangan kanan }\end{array}$ & 135 & 12 & 20 & 16,80 & 2,178 \\
\hline & $\begin{array}{l}\text { Tidak berkata-kata kotor, } \\
\text { kasar dan sombong }\end{array}$ & 135 & 19 & 35 & 27,63 & 3,711 \\
\hline & $\begin{array}{l}\text { Tidak meludah di } \\
\text { sembarang tempat }\end{array}$ & 135 & 4 & 10 & 7,82 & 1,588 \\
\hline & $\begin{array}{l}\text { Memberi salam setiap } \\
\text { Berjumpa guru }\end{array}$ & 135 & 8 & 20 & 15,42 & 2,736 \\
\hline & $\begin{array}{l}\text { Menghargai pendapat } \\
\text { Orang lain }\end{array}$ & 135 & 4 & 10 & 7,46 & 1,515 \\
\hline & $\begin{array}{l}\text { Meminti izin apabila } \\
\text { meminjam barang orang } \\
\text { lain }\end{array}$ & 135 & 4 & 10 & 8,12 & 1,526 \\
\hline
\end{tabular}

Berdasarkan tabel 2 dapat diketahui bahwa gambaran tingkat kecenderungan perilaku sopan santun yang dimiliki siswa yaitu 117,45 dari jumlah sampel 135 siswa. Jika mengacu pada kriteria tingkat analisis deskriptif pada tabel 4.1 maka dinyatakan bahwa tingkat perilaku sopan santun siswa berada pada kategori tinggi. Dan apabila dikaji lebih dalam dari indicator-indikator perilaku sopan santun tersebut maka dapat dilihat bahwa nilai tertinggi terdapat pada indicator menghormati orang yang lebih tua yaitu $\mathrm{M}=34.20, \mathrm{SD}=4.115$ dan nilai terendah pada indicator menghargai pendapat orang lain dengan nilai $\mathrm{M}=7.46, \mathrm{SD}=1.515$.

2. Tingkat Identitas Etnis pada Siswa Kelas X SMK Mataram Semarang

Tingkat indikator identitas etnis akan menunjukkan seberapa tinggi tingkat identitas etnis pada siswa. Untuk mengetahui kriteria analisis deskriptif pada setiap variabel dapat dilihat pada tabel dibawah ini :

Tabel 3. Kriteria Tingkat Analisis Deskriptif Identitas Etnis

\begin{tabular}{ccc}
\hline No & Kelas Interval & Kategori \\
\hline 1 & $96-120$ & Sangat Tinggi \\
2 & $80-95$ & Tinggi \\
3 & $64-79$ & Sedang \\
4 & $48-63$ & Rendah \\
5 & $23-47$ & Sangat Rendah \\
\hline
\end{tabular}

Data indikator identitas etnis di bawah akan menunjukkan seberapa tinggi tingkat identitas etnis pada siswa kelas X di SMK Mataram Semarang. Dianalisis pada setiap indikator secara keseluruhan berdasarkan rata-rata. Adapun tingkat data indikator identitas etnis disajikan dalam tabel sebagai berikut : 
Tabel 4. Hasil Analisis Tingkat Identitas Etnis

\begin{tabular}{cccccccc}
\hline Variabel & Indikator & N & Item & Min & Max & Mean & $\begin{array}{c}\text { Std. } \\
\text { Deviation }\end{array}$ \\
\hline \multirow{2}{*}{ Identitas Etnis } & Eksplorasi & 135 & 16 & 34 & 69 & 54,27 & 6,677 \\
& Komitmen & 135 & 8 & 21 & 39 & 30,53 & 3,781 \\
\hline
\end{tabular}

Berdasarkan tabel 4 maka didapatkan hasil tingkat identitas etnis yang dimiliki siswa yaitu 84,8 dari sampel 135 siswa kelas X di SMK Mataram Semarang. Apabila mengacu pada kriteria analisis deskriptif yang telah ditetapkan dalam tabel 4.3, maka dapat dinyatakan bahwa tingkat identitas etnis berada dalam kategori Tinggi. Dapat dilihat dalam indicator identitas etnis menunjukkan nilai tertinggi pada indicator Eksplorasi dengan skor $\mathrm{M}=54.27, \mathrm{SD}=6.677$ dan skor terendah pada indicator Komitmen dengan skor $\mathrm{M}=30.53, \mathrm{SD}=3.781$.

3. Tingkat Kesadaran Budaya pada Siswa Kelas X SMK Mataram Semarang

Tingkat indikator kesadaran budaya akan menunjukkan seberapa tinggi tingkat kesadaran budaya pada siswa. Untuk mengetahui kriteria analisis deskriptif pada variabel ini dapat dilihat pada tabel dibawah ini :

Tabel 5. Kriteria Tingkat Analisis Deskriptif Kesadaran Budaya

\begin{tabular}{ccc}
\hline No & Kelas Interval & Kategori \\
\hline 1 & $90-100$ & Sangat Tinggi \\
2 & $70-89$ & Tinggi \\
3 & $50-69$ & Sedang \\
4 & $30-49$ & Rendah \\
5 & $20-29$ & Sangat Rendah \\
\hline
\end{tabular}

Data indikator identitas etnis di bawah akan menunjukkan seberapa tinggi tingkat identitas etnis pada siswa kelas X di SMK Mataram Semarang. Dianalisis pada setiap indikator secara keseluruhan berdasarkan rata-rata. Adapun tingkat data indikator identitas etnis disajikan dalam tabel sebagai berikut :

Tabel 6. Hasil Analisis Tingkat Kesadaran Budaya

\begin{tabular}{clccccc}
\hline Variabel & \multicolumn{1}{c}{ Indikator } & N & Min & Max & Mean & $\begin{array}{c}\text { Std. } \\
\text { Deviation }\end{array}$ \\
\hline & $\begin{array}{l}\text { Adanya pengetahuan } \\
\text { tentang kebudayaan } \\
\text { Adanya sikap menghargai } \\
\text { Kesadaran } \\
\text { Budaya }\end{array}$ & 135 & 22 & 45 & 34,45 & 4,554 \\
& $\begin{array}{l}\text { dan memahami akan budaya } \\
\text { Mampu merawat dan } \\
\text { mengembangkan warisan } \\
\text { budaya }\end{array}$ & 135 & 8 & 24 & 17,57 & 2,544 \\
\hline
\end{tabular}


Berdasarkan tabel 6 diatas dapat diketahui bahwa nilai skor rata-rata tingkat kesadaran budaya yang dimiliki siswa yaitu 74,97 dari 135 siswa. Apabila mengacu pada kriteria yang telah ditetapkan pada tabel 3.2 maka dapat dinyatakan bahwa rata-rata tingkat kesadaran budaya berada pada kategori tinggi. Jika dilihat dari indicator maka menunjukkan nilai adanya pengetahuan tentang kebudayaan : $\mathrm{M}=34.45, \mathrm{SD}=4.554$; adanya sikap menghargai dan memahami akan budaya : $\mathrm{M}=17.57, \mathrm{SD}=2.544$; mampu merawat dan mengembangkan warisan budaya: $\mathrm{M}=22.95$, $\mathrm{SD}=3.238$. Dapat dilihat bahwa nilai tertinggi terdapat pada indikator pertama dan nilai terendah pada indikator kedua.

Kemudian untuk mengetahui dan membuktikan ada tidaknya hubungan antar variabel maka dilakukan pengujian menggunakan uji regresi ganda yaitu membuktikan ada tidaknya hubungan antara identitas etnis dengan kecenderungan perilaku sopan santun, hubungan antara kesadaran budaya dengan kecenderungan perilaku sopan santun dan hubungan antara identitas etnis dan kesadaran budaya dengan kecenderungan perilaku sopan santun. Pada hasil uji regresi dapat dilihat pada tabel sebagai berikut :

Tabel 4. Hasil Uji Regresi Ganda

\begin{tabular}{lcccccc}
\hline \multicolumn{1}{c}{ Prediktor } & $\mathbf{R}$ & $\mathbf{R}^{2}$ & $\mathbf{F}$ & $\boldsymbol{\beta}$ & $\mathbf{t}$ & Sig. \\
\hline Identitas Etnis dan Kesadaran & \multirow{2}{*}{0,481} & 0,232 & 19,918 & & & 0,000 \\
Budaya & & & & 0,360 & 3,651 & 0,000 \\
Identitas Etnis & & & & 0,165 & 1,677 & 0,096 \\
Kesadaran Budaya & & &
\end{tabular}

Berdasarkan hasil analisis dalam tabel 4 diperoleh hasil antara identitas etnis dan perilaku sopan santun terdapat hubungan yang positif dan signifikan $(\beta=0,360 ; \mathrm{t}=3,651 ; \mathrm{p}=0,000)$. Berdasarkan nilai $\mathrm{p}<0,05$, Maka dapat disimpulkan bahwa pada hipotesis variabel (X1) "ada hubungan antara identitas etnis dengan kecenderungan perilaku sopan santun pada siswa kelas X SMK Mataram Semarang”. Selanjutnya pada hasil antara kesadaran budaya dengan kecenderungan perilaku sopan santun tidak terdapat hubungan yang positif dan signifikan $(\beta=$ 0,165; $\mathrm{t}=1,677 ; \mathrm{p}=0,096$ ). Berdasarkan nilai $\mathrm{p}=<0,05$, Sehingga dapat disimpulkan bahwa pada hipotesis variabel (X2) ini tidak memiliki hubungan atau "tidak ada hubungan antara kesadaran budaya dengan kecenderungan perilaku sopan santun pada siswa kelas X SMK Mataram Semarang". Kemudian berdasarkan hasil analisis dalam pengujiannya menggunakan bantuan program SPSS versi 16.0, dimana hasil tersebut menunjukkan bahwa antara identitas etnis dan kesadaran budaya dengan kecenderungan perilaku sopan santun terdapat hubungan yang signifikan dengan $(\mathrm{R}=0,481 ; \mathrm{F}=19,918 ; \mathrm{p}=0,000)$, nilai $\mathrm{p}<0,05$. Berdasarkan tabel 4 maka diperoleh koefisien determinasi sebesar 0,232 yang dapat dilihat bahwa presentase sumbangan identitas etnis dan kesadaran budaya pada siswa sebesar 23,2\%. Sedangkan sisanya sebesar 76,8\% dan dapat diprediksi oleh variabel lain yang tidak diteliti. Selain itu signifikansi 0,000 artinya kurang dari < 0,05 Sehingga jawaban hasil analisis dapat disimpulkan bahwa "ada hubungan antara identitas etnis dan kesadaran budaya dengan kecenderungan perilaku sopan santun pada siswa kelas X SMK Mataram Semarang”. 


\section{Diskusi}

Penelitian ini dimaksudkan untuk mengetahui tingkat hubungan identitas etnis dan kesadaran budaya dengan kecenderungan perilaku sopan santun serta untuk mengetahui ada tidaknya hubungan antara identitas etnis dan kesadaran budaya dengan kecenderungan perilaku sopan santun pada siswa kelas X SMK Mataram Semarang. Sesuai dengan analisis deskriptif kuantitatif dan analisis product moment yang telah dijelaskan maka akan lebih diperjelas dalam pemabahasan ini. Pada hasil penelitian ini diharapkan dapat memberikan pengetahuan baru terkait dengan topik yang telah diangkat dan diteliti dan juga penelitian ini diharapkan dapat menjadi referensi atau acuan baru bagi peneliti lain yang ingin meneliti dengan topik penelitian yang serupa. Berdasarkan pada penelitian yang telah dilakukan ini maka dapat diketahui bahwa terdapat hubungan yang signifikan antara identitas etnis dan kesadaran budaya dengan kecenderungan perilaku sopan santun pada siswa kelas X di SMK Mataram Semarang. Selain itu Berdasarkan penelitian yang dilakukan Herlangga (2017) "Faktor hilangnya perilaku santun dalam bingkai budaya jawa" hasil penelitian tersebut menyatakan bahwa faktor hilangnya perilaku sopan santun dipengaruhi oleh teman sebaya dan lingkungan sekitar sehingga memiliki perbedaan anatara perilaku santun dahulu dan sekarang, dimana perilaku santun dulu masih sangat erat dan melekat pada masyarakat terutama remaja karena belum adanya pengaruh dari luar,namun perilaku santun sekarang sudah mulai luntur karena adanya gaya dan pengaruh budaya dari luar.

Trandis (2017) menyebutkan bahwa budaya merupakan hasil interaksi adaptif anatara orang-orang dengan lingkungannya, yang dibagi dan disosialisasikan dari generasi ke generasi selanjutnya, namun budaya pada gilirannya justru akan berpengaruh dan membentuk kepribadian dan perilaku manusia (Schultz \& Schultz, 2005). Selain itu Rahman (2017) juga menyatakan bahwa hidup dalam suatu konteks budaya pasti memberikan efek terhadap pembentukan perilaku dan aspek psikologis, aspek perialku tersebut salah satunya adalah perilaku sopan santun. Perkembangan teknologi komunikasi dan transportasi pada masa ini membuat interaksi antar etnik semakin terbuka akibat menurunnya karakter dan identitas etnis pada remaja. Sehingga penguatan identitas etnis dan penananaman sikap sopan santun pada siswa perlu ditingkatkan kembali. Hal tersebut juga dikarenakan penguatan identitas etnis tingginya perasaan sejahtera dan penyesuaian sosial.

Rahman (2018) menyatakan dari hasil penelitian bahwa sebagian besar identitas etnis responden termasuk kedalam kategori kuat, artinya responden menunjukkan penghayatan yang baik terhadap nilai-nilai kebudayaan yang dimilikinya. Orang yang menghayati suatu nilai termasuk nilai kebudayaan yang dimiliki diduga akan menunjukkan nilai-nilai kebudayaan tersebut dalam kehidupan sehari-hari. Selain itu responden juga menyadari bahwa karakteristik utama dalam salah satu budaya adalah perilaku sopan santun selain itu perilaku ramah menjadi karakteristik kedua terbesar yang harus dimiliki, sehingga dengan pengetahuan yang dimilikinya maka seharusnya dapat diaplikasikan dalam kehidupan sehari-hari walaupun hal tersebut masih sangat dipengaruhi oleh faktor-faktor lainnya. Dari beberapa hasil penelitian diatas bahwa perilaku sopan santun adalah salah satu nilai dan karakteristik dari faktor budaya dan budaya itu sendri tidak dapat terlepas dari adanya identitas etnis. Hal ini berarti jika seseorang tidak berperilaku sopan santun dan menemukan dirinya akan kesadaran budaya dan identitas etnis yang dimilikinya maka akan berpikir ulang untuk dapat mengamalkan atau menanamkan nilai-nilai budaya salah satunya perilaku sopan santun dalam kehidupan sehari-hari. 
Pada kedua variabel independen dalam penelitian ini yakni identitas etnis dan kesadaran budaya adalah tidak sepenuhnya indicator yang dapat mempengaruhi perilaku sopan santun pada siswa. Karena banyak faktor-faktor lain yang dapat mempengarhui perilaku sopan santun pada siswa. Pada identitas etnis dan kesadaran budaya menjadi sebagian kecil yang dapat mempengaruhi perilaku sopan santun. Oleh karena itu unutuk meningkatkan perilaku sopan santun pada siswa perlu diperhatikan dan dikaji lebih dalam tentang nilai-nilai kesopanan. Pemahaman dan pembelajaran nilai kebudayaan dan sopan santun dari berbagai pihak khususnya orangtua dan guru disekolah sangat dibutuhkan untuk dapat menambah wawasan, pemahaman dan pengaplikasian dalam meningkatkan nilai kesopanan dan kebudayaan. Dari hasil penelitian secara keseluruhan menunjukkan adanya hubungan yang positif dan signifikan antara identitas etnis dan kesadaran budaya dengan kecenderungan perilaku sopan santun pada siswa kelas X SMK Mataram Semarang. Dapat dikatakan bahwa identitas etnis dan kesadaran budaya secara bersama-sama memiliki perananan dan kontribusi terhadap tingkat perilaku sopan santun pada siswa, namun tidak sepenuhnya identitas etnis dan kesadaran budaya memiliki pengaruh terhadap perilaku sopan santun. Hal ini dikarenakan masih banyak terdapat faktor lain yang kemungkinan besar dapat berpengaruh dalam meningkatkan perilaku sopan santun pada siswa.

Berdasarkan pada penelitian yang telah dilakukan maka diperoleh hasil yang dapat menjawab rumusan masalah pada penelitian. Penelitian ini telah disusun dengan sebaik-baiknya, namun masih terdapat keterbatasan dalam menulis dan melaksankan penelitian ini. Adapun keterbatasan dalam penelitian ini yaitu (1) Dalam melaksanakan penelitian, peneliti mengalami hambatan dimana para siswa yang akan menjadi subjek penelitian banyak yang sedang melaksankan PKL (Praktik Kerja Lapangan), namun guru BK memberikan solusi untuk mengganti subjek atau sampel penelitian pada kelas lain yang tidak sedang melaksanakan PKL. (2) Selain itu dalam pelaksanaan penelitian sekolah yang akan diteliti mendekati masa ujian tengah semester sehingga peneliti dianjurkan untuk menunggu ujian selesai yaitu kurang lebih 1 minggu. (3) Peneliti kesulitan dalam mencari acuan atau referensi dari peneliti sebelumnya.

Berdasarkan dari hasil penelitian tentang hubungan antara identitas etnis dan kesadaran budaya dengan kecenderungan perilaku sopan santun pada siswa kelas X SMK Mataram Semarang, maka dapat diajukan saran bagi konselor sekolah, agar dapat dijadikan acuan bagi guru bk untuk lebih menguatkan dan memberikan pengetahuan lebih dengan menggunakan layanan klasikal, BKp maupun KKp untuk lebih menguatkan siswa dalam memahami identitas etnis dan budaya nya agar mampu menanamkan nilai-nilai sopan santun dalam kehidupan sehari-hari. Kemudian bagi peneliti selanjutnya, diharapkan bagi peneliti selanjutnya dapat melakukan pengembangan penelitian mengenai hubungan identitas etnis dan kesadaran budaya dengan kecenderungan perilaku sopan santun, sehingga disarankan bagi peneliti selanjutnya untuk dapat menggunakan varaiabel-variabel yang lebih variatif, mendalam dan spesifik. Agar dapat diketahui lebih besar tingkat kecenderungan perilaku sopan santun dengan variabel lain yang lebih bervariasi

\section{Simpulan}

Hasil penelitian menunjukkan bahwa identitas etnis dan kesadaran budaya memiliki pengaruh yang signifikan terhadap kecenderungan perilaku sopan santun dengan perolehan $\mathrm{R}=0,481 ; \mathrm{R} 2=0,232 ; \mathrm{F}=19,918$; dan nilai sig=0,000. Nilai taraf signifikansi sebesar 0,000 
$(\mathrm{P}<0,05)$ menunjukkan bahwa identitas etnis dan kesadaran budaya berhubungan secara signifikan terhdap kecenderungan perilaku sopan santun.

\section{Referensi}

Arianto, A. (2014). Manipulasi Identitas Etnik Jawa dalam Komunikasi Antarbudaya di Kota Makasar. Jurnal Ilmu Komunikasi, 10(3), 295-307.

Budiyono, B., \& Feriandi, Y. A. (2017). Menggali Nilai Nilai Kearifan Lokal Budaya Jawa Sebagai Sumber Pendidikan Karakter. In Prosiding Seminar Nasional Bimbingan dan Konseling (Vol. 1, No. 1, pp. 92-103).

Hartomo, R. (2008). Perbedaan Sikap Terhadap Tata Krama Jawa dalam Menghormati Orang Tua pada Remaja Desa dan Remaja Kota. Universitas Sanata Dharma Yogyakarta.

Herlangga, O. (2017). Faktor-faktor penyebab hilangnya perilaku santun dalam bingkai budaya jawa. Skripsi tidak diterbitkean. Universitas Pendidikan Indonesia, Bandung.

Hurlock, E. B. (1992). Psikologi Perkembangan : Suatu Pendekatan SepanjangRentang Kehidupan. Jakarta : Erlangga Khatimah

Koentjaningrat. (1980). Manusia Dan Kebudayaan di Indonesia. Jakarta: Djambatan

Koentjaraningrat. (1994). Kebudayaan Jawa. Jakarta : Balai Pustaka

Oktasari, D., Yandri, H., \& Juliawati, D. (2020). Analisis Pelanggaran Tata Tertib Sekolah oleh Siswa dan Peran Guru Bimbingan dan Konseling di Sekolah. Jurnal Mahasiswa BK An-Nur: Berbeda, Bermakna, Mulia, 6(4), 16-21.

Risthantri, P., \& Sudrajat, A. (2015). Hubungan antara pola asuh orang tua dan ketaatan beribadah dengan perilaku sopan santun peserta didik. Harmoni Sosial: Jurnal Pendidikan IPS, 2(2), 191-202.

Riyanti, P. (2013). Relasi sosial pedagang Etnis Cina dan Etnis Jawa di pasar tradisional. Komunitas: International Journal of Indonesian Society and Culture, 5(1).

Santrock, W. J. (2003). Adolecent, Perkembangan Remaja. Jakarta: Erlangga.

Sugiyono. (2015). Metode Penelitian Pendidikan . Bandung: Alfabeta

Suharti. (2004). Pendidikan Sopan Santun dan Kaitannya dengan Perilaku Berbahasa Jawa Mahasiswa. Pendidikan, 57-71.

Suryani, L. (2017). Upaya Meningkatkan Sopan Santun Berbicara Dengan Teman Sebaya Melalui Bimbingan Kelompok. E-Jurnal Mitra Pendidikan, 1(1), 112-124.

Sutoyo, A. (2014). Pemahaman Individu, Observasi, Checklis, Interviu, Kuesioner, Sosiometri. Yogyakarta : Pustaka Pelajar

Yandri, H. (2016). Kepribadian Konselor dan Pembentukan Karakter Siswa di Sekolah. Tarbawi: Jurnal Ilmu Pendidikan, 1(1). 